\section{DiscoverSys \\ Published by DiscoverSys \\ Risk factors of pre-eclampsia in Dompu District, West Nusa Tenggara Province}

\author{
Maria Ulfah, ${ }^{1 *}$ Ni Luh Putu Suariyani, ${ }^{2,3}$ Dyah Pradnyaparamita Duarsa ${ }^{2,4}$
}

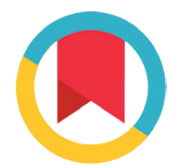

CrossMark

\section{Abstract}

Background and purpose: Pre-eclampsia is a major contributing factor of maternal mortality. Dompu District has a high rate of maternal mortality relative to the rest of districts in West Nusa Tenggara Province. Pre-eclampsia is the major cause of maternal mortality in Dompu District. This study aims to examine risk factors of pre-eclampsia among pregnant women.

Methods: A case control study was conducted in five public health centres in Dompu District. A total of 104 women who gave birth and have diagnosed with pre-eclampsia during the pregnancy were recruited as cases. A total of 104 women who gave girth and did not have pre-eclampsia were selected as controls. All cases and controls were selected using a systematic random sampling technique from the
2016 pregnant women cohort at five public health centres. Data were collected through interview and extraction from the maternal and child health book. Data were analysed using bivariate and multivariate techniques.

Results: Our multivariate analysis found that pre-eclampsia was associated with parity of 1 or $>3$ ( $A O R=3.64 ; 95 \% \mathrm{Cl}: 1.85-7.17)$, body mass index of $>27.0 \mathrm{~kg} / \mathrm{m}^{2}(\mathrm{AOR}=3.01 ; 95 \% \mathrm{Cl}$ : 1.39-6.48), history of chronic diseases ( $A O R=16.43 ; 95 \% \mathrm{Cl}: 3.32-81.22)$ and smoke exposure (AOR=3.71; 95\%Cl: 1.95-7.05).

Conclusions: Parity of 1 and $>3, \mathrm{BMl}$ of $>27.0 \mathrm{~kg} / \mathrm{m}^{2}$, history of chronic illnesses and smoke exposure are risk factors for pre-eclampsia in Dompu District, West Nusa Tenggara.
${ }^{1}$ Dompu District Health Office, ${ }^{2}$ Public Health Postgraduate Program Udayana University, ${ }^{3}$ chool of Public Health Faculty of Medicine Udayana University, ${ }^{4}$ Department of Community and Preventive Medicine Faculty of Medicine Udayana University

${ }^{*}$ Correspondence to:

Maria Ulfah, Dompu District Health Office

hj.ulfah_80@yahoo.com

Keywords: risk factor, pre-eclampsia, pregnant women, West Nusa Tenggara

Cite This Article: Ulfah, M., Suariyani, N.L.P., Duarsa, D.P. 2017. Risk factors of pre-eclampsia in Dompu District, West Nusa Tenggara Province. . Public Health and Preventive Medicine Archive 5(2): 112-116. D0l:10.15562/phpma.v5i2.24

\section{INTRODUCTION}

Maternal mortality ratio (MMR) is an essential indicator for health status of the population and is one among many indicators for Sustainable Development Goals (SDGs). ${ }^{1}$ Indonesia is one country in Asia Region that failed to achieve the Millennium Development Goals (MDGs) target for MMR of 102 per 100,000 live births in 2015 . $^{2}$ The 2012 National Demographic and Health Survey indicated that the MMR in Indonesia was increased from 228 per 100,000 live births in 2010 to 359 per 100,000 live births in $2012 .^{2}$ Pre-eclampsia is one among many causes of maternal mortality in Indonesia with an increased proportion from $21.5 \%$ in 2010 to $27.1 \%$ in 2013 . $^{3}$

The reported cases of maternal mortality in West Nusa Tenggara Province is 92 per 100,000 live births. This reported cases is slightly lower than the national MMR target of 102 per 100,000 live births. As many as $26.7 \%$ of maternal mortality in this province is contributed by pre-eclampsia. ${ }^{4}$ Dompu District contributes the most to overall maternal mortality cases in West Nusa Tenggara Province. Total maternal mortality cases in Dompu District tends to increase every year - from 113 in 2013, 126 in 2014 , and 223 per 100,000 live births in $2015 .{ }^{4}$ As many as $41.7 \%$ of these maternal mortality cases were contributed by pre-eclampsia. ${ }^{5}$
Several studies have reported that pre-eclampsia among women who live in rural areas is associated with being married for more than once, parity, birth space of less than two years, primigravida, unemployed, previous history of pre-eclampsia, obesity, stress, nulliparity, diabetes mellitus, history of chronic hypertension, smoking, smoke exposure and aged $\geq 35$ years. ${ }^{6-9}$ Risk factors associated to pre-eclampsia in Dompu District - West Nusa Tenggara Province are rarely been reported, however data from the 2013 National Basic Health Research indicated that several factors might explain a high prevalence of pre-eclampsia in Dompu District or West Nusa Tenggara Province. As many as $10.23 \%$ of population in West Nusa Tenggara were obese, the prevalence of diabetes mellitus and hypertension among adult population ( $\geq 18$ years) were $1.3 \%$ based on professional diagnosis and $24.3 \%$ based on blood pressure measurement. In addition, West Nusa Tenggara was ranked $7^{\text {th }}$ nationally on the total tobacco consumption among adult population (aged $\geq 15$ years). ${ }^{10}$

Studies on risk factors of pre-eclampsia in Indonesia, particularly in West Nusa Tenggara are still limited. Studies exploring risk factors of pre-eclampsia are required to guide interventions and decisions made by policy makers to lower the 
MMR. Our study aims to examine factors associated with pre-eclampsia among pregnant women in Dompu District, West Nusa Tenggara Province.

\section{METHODS}

A case control study was conducted using case and control ratio of 1:1. Cases were women who gave birth and have been diagnosed with pre-eclampsia. Controls were women who gave birth and did not have pre-eclampsia. Pre-eclampsia was defined as a new onset of hypertension that occurred after 20 weeks' gestation and accompanied by proteinuria. ${ }^{11}$ Cases and control were selected using a systematic random sampling technique from the 2015 pregnant women cohort at five public health centres in Dompu District. Four out of eight sub-districts were purposively selected based on the geographical consideration that were sub-district of Dompu, Pajo, Woja, and Pekat. From 238 women who gave birth and have been diagnosed with pre-eclampsia in these four sub-districts, a total of 104 women were recruited as cases. From 467 women who gave birth and did not have pre-eclampsia, a total of 104 women were selected as controls. Frequency matching was done by age.

Samples for both control and case groups were screened based on several inclusion and exclusion criteria. Inclusion criteria included: (1) women who gave birth and registered at the public health centre cohort between January and December 2016; and (2) these women must conducted their first antenatal care during the first trimester. Exclusion criteria included: (1) women who resided outside of Dompu District; (2) women who have died during the pregnancy and delivery; (3) women who did not have a mother and child health $(\mathrm{MCH})$ book; and (4) women who refused to participate in the study. Data were collected through interview and secondary data from the $\mathrm{MCH}$ book. Data on demographic characteristics (age, education, employment, family income, parity, and birth spacing) and smoke exposure were collected through home interview using a structured questionnaire. Written informed consent was obtained from all respondents prior to the data collection. Data on health status of the mother were collected from the MCH book which included height, weight, and other chronic conditions. Family income was classified into low income if they earned less than IDR $1,350,000$ and high if they earned more than IDR 1,350,000 per month. This cut-off was based on the minimum wage standard in Dompu District. ${ }^{12}$ History of chronic diseases included hypertension and diabetes mellitus which both are risk factors for pre-eclampsia. ${ }^{11}$ Level of education was divided into $\leq$ junior high school ( $\leq$ year 9 ) and $>$ junior high school (>year 9). ${ }^{13}$ Exposure to smoke was defined not only being exposed by their husband but also by their surrounding people. Body mass index (BMI) was calculated from body weight and height on the first trimester. ${ }^{10}$

Risk factors for pre-eclampsia were determined using a backward logistic regression analysis. This study protocol has been approved by the Human Research Ethics Committees Faculty of Medicine Udayana University/Sanglah General Hospital Denpasar.

\section{RESULTS}

Table 1 shows that cases and controls were comparable by age ( 29.47 vs. 28.83 years) and birth spacing (49.66 vs. 46.82 months). The proportion of women who gave birth was higher in Dompu and Woja Sub-Districts than Pajo and Pekat Sub-districts.

Table 2 shows that several variables were found to have significant association $(\mathrm{p}<0.05)$ with pre-eclampsia which included education, parity, obesity, history of chronic diseases, smoke exposure and source of smoke exposure. These variables were all included in the multivariate analysis.

Multivariate analysis (Table 3) shows that pre-eclampsia was associated with parity 1 and

Table 1 Comparison of demographic characteristics between cases and controls

\begin{tabular}{lcccc}
\hline & Case & & Control & p value \\
\cline { 2 - 3 } Characteristics & $\mathbf{n}(\%)$ & $\mathbf{n}(\%)$ & 0.637 \\
Age (year), mean \pm SD & $29.47 \pm 6.75$ & & $28.83 \pm 6.66$ & 0.083 \\
Birth spacing (month), mean \pm SD & $49.66 \pm 40.59$ & & $46.82 \pm 31.32$ & 0.924 \\
Sub-district or domicile & & & \\
$\quad$ Dompu & $44(42.31)$ & & $45(43.27)$ & \\
Pajo & $16(15.38)$ & & $9(13.46)$ & \\
$\quad$ Pekat & $11(10.58)$ & $36(34.62)$ & \\
$\quad$ Woja & $33(31.73)$ & & $104(100.00)$ \\
Total & $104(100.00)$ & & \\
\hline
\end{tabular}


Table 2 Association between pre-eclampsia and demographic characteristics, health status and smoke exposure

\begin{tabular}{|c|c|c|c|c|c|c|c|}
\hline \multirow[b]{2}{*}{ Variables } & \multicolumn{2}{|c|}{ Case } & \multicolumn{2}{|c|}{ Control } & \multirow[b]{2}{*}{ Crude OR } & \multirow[b]{2}{*}{$95 \% \mathrm{Cl}$} & \multirow[b]{2}{*}{ p value } \\
\hline & $\mathbf{n}$ & $\%$ & $\mathbf{n}$ & $\%$ & & & \\
\hline \multicolumn{8}{|l|}{ Education } \\
\hline syear 9 & 57 & $(54.81)$ & 41 & $(39.42)$ & 1.86 & $1.03-3.35$ & 0.026 \\
\hline >year 9 & 47 & $(45.19)$ & 63 & $(60.58)$ & & & \\
\hline \multicolumn{8}{|l|}{ Employment status } \\
\hline Employed & 26 & $(25.00)$ & 30 & $(28.85)$ & 0.82 & $0.42-1.58$ & 0.531 \\
\hline Not employed & 78 & $(75.00)$ & 74 & $(71.15)$ & & & \\
\hline \multicolumn{8}{|l|}{ Family income } \\
\hline$<$ IDR $1,350,000$ & 48 & $(46.15)$ & 45 & $(43.27)$ & 1.12 & $0.63-2.01$ & 0.676 \\
\hline$\geq \operatorname{IDR} 1,350,000$ & 56 & $(53.85)$ & 59 & $(56.73)$ & & & \\
\hline \multicolumn{8}{|l|}{ Parity } \\
\hline 1 and $>3$ & 58 & $(55.77)$ & 42 & $(40.38)$ & 1.86 & $1.03-3.35$ & 0.026 \\
\hline $2-3$ & 46 & $(44.23)$ & 62 & $(59.62)$ & & & \\
\hline \multicolumn{8}{|l|}{ BMI } \\
\hline $\mathrm{BMI}>27.0 \mathrm{~kg} / \mathrm{m}^{2}$ (obese) & 35 & $(33.65)$ & 19 & $(18.27)$ & 2.27 & $1.14-4.58$ & 0.011 \\
\hline $\mathrm{BMI} \leq 27.0 \mathrm{~kg} / \mathrm{m}^{2}$ (not obese) & 69 & $(66.35)$ & 85 & $(81.73)$ & & & \\
\hline \multicolumn{8}{|l|}{ History of chronic diseases } \\
\hline Yes & 19 & $(18.27)$ & 2 & $(1.92)$ & 11.4 & $1.79-102.75$ & 0.001 \\
\hline No & 85 & $(81.73)$ & 102 & $(98.08)$ & & & \\
\hline \multicolumn{8}{|l|}{ Type of chronic diseases } \\
\hline Hypertension & 17 & $(16.35)$ & 2 & $(1.92)$ & 9.27 & $2.07-84.61$ & 0.006 \\
\hline Diabetes mellitus & 2 & $(1.92)$ & 0 & $(0.00)$ & & & \\
\hline No complication & 85 & $(81.73)$ & 102 & $(98.08)$ & & & \\
\hline \multicolumn{8}{|l|}{ Smoke exposure } \\
\hline Exposed & 62 & $(59.62)$ & 33 & $(31.73)$ & 3.17 & $1.79-5.85$ & 0.001 \\
\hline Not exposed & 42 & $(40.38)$ & 71 & $(68.27)$ & & & \\
\hline \multicolumn{8}{|l|}{ Source of smoke exposure } \\
\hline Husband & 58 & $(55.77)$ & 31 & $(29.81)$ & 3.03 & $1.65-5.53$ & 0.001 \\
\hline Work place & 4 & $(3.85)$ & 2 & $(1.92)$ & & & \\
\hline Not exposed & 42 & $(40.38)$ & 71 & $(68.27)$ & & & \\
\hline Total & 104 & $(100.00)$ & 104 & $(100.00)$ & & & \\
\hline
\end{tabular}

Table 3 Adjusted odd ratio (AOR) of pre-eclampsia

\begin{tabular}{lccc}
\hline Variables & Adjusted odd ratio & $\mathbf{9 5 \%} \mathbf{C l}$ & p value \\
\hline Parity of 1 and $>3$ & 3.64 & $1.85-7.17$ & 0.000 \\
History of chronic diseases & 16.43 & $3.32-81.22$ & 0.001 \\
BMI of $>27.0 \mathrm{~kg} / \mathrm{m}^{2}$ & 3.01 & $1.39-6.48$ & 0.005 \\
Smoke exposure & 3.71 & $1.95-7.05$ & 0.000 \\
\hline
\end{tabular}

$>3(\mathrm{AOR}=3.64 ; 95 \% \mathrm{CI}: 1.85-7.17), \mathrm{BMI}$ of $>27.0$ $\mathrm{kg} / \mathrm{m}^{2} \quad$ (AOR=3.01; 95\%CI: 1.39-6.48), history of chronic diseases (AOR $=16.43$; 95\%CI: 3.32$81.22)$ and smoke exposure (AOR=3.71; 95\%CI: $1.95-7.05)$.

\section{DISCUSSION}

Published research related to risk factors for pre-eclampsia among pregnant women in Indonesia is very limited. Our study which took place in West 
Nusa Tenggara Province provides essential information regarding risk factors of pre-eclampsia in East Indonesia Region. Our study found that risk factors of pre-eclampsia among pregnant women included parity of 1 or $>3$, BMI of $>27.0 \mathrm{~kg} / \mathrm{m}^{2}$, history of chronic diseases and smoke exposure.

Women with parity of one or more than three are at risk for developing pre-eclampsia. Women with parity of one may be related to the young age of pregnant women, and young women have a higher risk of pre-eclampsia. ${ }^{6}$

Our finding is consistent with a study conducted at Soeselo Tegal District General Hospital in Central Java. ${ }^{14}$ In addition, a case control study in Cairo also documented that parity is a risk factor of pre-eclampsia. ${ }^{6}$ However, other study conducted at Padang District General Hospital, West Sumatra Province, found that parity of 1 or $>3$ was not associated with pre-eclampsia. ${ }^{15}$ Similar finding was also reported by a study in Tangerang, Banten which revealed that there was no association between parity and pre-eclampsia. ${ }^{16}$ These two study that found no association between parity and pre-eclampsia were hospital-based studies, while our study was a community-based research at community health centres. We also suspect that the difference of demographic characteristics of samples used in the existing studies as well as our study leads to inconsistency of association between parity and pre-eclampsia. This indicates the need for further investigation.

Our study found that a BMI of $>27.0 \mathrm{~kg} / \mathrm{m}^{2}$ was associated with increased risk of pre-eclampsia among pregnant women. Our finding is consistent with a number of studies conducted in Manado Indonesia, Cairo and the US. ${ }^{6,8,17,18}$ However, a case control study conducted in Padang, West Sumatera found that there was no association between obesity and pre-eclampsia. ${ }^{15}$ The setting of this study was at the Padang District Hospital, which allows coordinated services across departments to screen high risk pregnancy and non-communicable diseases including obesity during pregnancy. The use of $\mathrm{BMI}$ as an indicator for pre-eclampsia risk factor is subjected to further investigation. A meta-analysis by collecting data from developed countries (the US, Australia, Cina, France, Japan, and the Netherland) found that BMI is a weak predictor for pre-eclampsia. ${ }^{19}$ It is still unclear however if the different characteristics of population in this meta-analysis and in Indonesia context will lead to different finding or not. In those developed countries, they also conduct a thorough bio-psycho-socio assessment to screen potential risks during pregnancy, ${ }^{19}$ whereas these assessments are not part of the current antenatal care practices in Indonesia.
Our study found that history of chronic diseases especially hypertension among pregnant women was associated with increased risk of pre-eclampsia. This finding is consistent with several studies conducted in Indonesia or other countries. A cohort study in Swedia, a systematic review in Asia, Africa, and America, as well as a cross-sectional retrospective study have documented that women with chronic diseases are at increased risk of developing pre-eclampsia. ${ }^{8,20,21}$ In addition, a study conducted in Tangerang, Banten also revealed similar finding. ${ }^{16}$

This study showed that pregnant women who were exposed to smoke were at higher risk for developing pre-eclampsia - where most of the exposure came from the husband (55.77\%). Our finding is consistent with other studies conducted in district hospital in Solo Province as well as Portuguese which found that smoke exposure was a risk factor of pre-eclampsia. ${ }^{79}$ However, several studies in other countries revealed that there was no association between smoke exposure and pre-eclampsia. A case control study in Egypt and a cross-sectional study in Norwegian found that women who were exposed to smoke were at lower risk of developing pre-eclampsia. ${ }^{6,8}$

Current antenatal care services are directed to detect high risk pregnancies however they do not aim at identifying its underlying risk factors. The screening for pre-eclampsia at Dompus District is done during the $2^{\text {nd }}$ trimester through urinalysis to identify proteinuria. The antenatal care services should also be able to detect risk factors for pre-eclampsia by exploring parity, obesity, chronic diseases and smoke exposure. The free-smoking zone should also be extended to household level, especially by providing counselling to the husband during antenatal care services. A cross-program and cross-sector partnership should also be strengthen especially in identifying barriers to and enablers of birth spacing, monitoring of nutritional status of pregnant women, detection of chronic diseases, and smoking prevention in order to reduce the prevalence of pre-eclampsia.

Due to the nature of our study design, it may be vulnerable to recall bias. Our respondents should recall the past events for example whether they were exposed to smoke in the past or not. We also purposively selected study locations based on the geographic consideration thus it may limit the external validity of our study to a wider population.

\section{CONCLUSION}

Parity of 1 and $>3$, BMI of $>27.0 \mathrm{~kg} / \mathrm{m}^{2}$, history of chronic illnesses and smoke exposure are risk 
factors for preeclampsia in Dompu District, West Nusa Tenggara. Identification and prevention of these risk factors must be incorporated in the antenatal care and other public health program.

\section{ACKNOWLEDGEMENT}

We would like to thank all public health centres in Dompu District, all respondents and other stakeholders who have supported this study.

\section{REFERENCES}

1. World Health Organization. Trends in maternal mortality: 1990 to 2013. Geneva: World Health Organization; 2014.

2. The National Demography and Family Planning Agency. Survei Demografi dan Kesehatan Indonesia (SDKI) tahun 2012 [The 2012 National Demographic and Health Survey]. Jakarta: The National Demography and Family Planning Agency; 2013.

3. Ministry of Health of Indonesia. Profil Kesehatan Indonesia Tahun 2014 [The 2014 Indonesia Health Profile]. Jakarta: Ministry of Health of Indonesia; 2015.

4. NTB Province Health Office. Profil kesehatan Provinsi NTB Tahun 2015 [The 2015 NTB Province Health Profile]. Mataram: NTB Province Health Office; 2016.

5. Dompu District Health Office. Profil Dinas Kesehatan Kabupaten Dompu Tahun 2015 [The 2015 Dompu District Health Office Profile]. Dompu: Dompu District Health Office; 2016

6. El-Moselhy, Essam A., et al. Risk factors and impacts of pre-eclampsia: An epidemiological study among pregnant mothers in Cairo, Egypt. Journal of American Science 7.5.2011: 311-323.

7. Jeyabalan A, Powers RW, Durica AR., et al. Cigarette smoke exposure and angiogenic factors in pregnancy and preeclampsia. American Journal of Hypertension. 2008; 21: 943-947.

8. Conde-Agudelo A, Belizán JM. Risk factors for pre-eclampsia in a large cohort of Latin American and Caribbean women. BJOG. 2000; 107: 75-83.

9. Isnawati M. Hubungan ibu hamil sebagai perokok pasif dengan kejadian preeklampsia Di RSUD Dr. Moewardi [Association between being passive smoker and the occurrence of preeclampsia among pregnant women at Dr Moewardi District General Hospital] (Thesis). Surakarta: University of Sebelas Maret; 2012.

10. Ministry of Health of Indonesia. Riset Kesehatan Dasar (Riskesdas) Tahun 2013 [The 2013 Basic Health Research]. Jakarta: Ministry of Health of Indonesia; 2013.
11. Prawirohardjo S. Ilmu kebidanan [Midwifery science]. Jakarta: Yayasan Bina Pustaka Sarwono Prawirohardjo; 2014.

12. NTB Provincial Government. Keputusan Gubernur tentang upah minimum kabupaten dompu tahun 2015 [The Governor Regulation on Minimum Wages at Dompu District in 2015]. Mataram: NTB Provincial Government; 2014.

13. The Indonesian Government. PP Nomor 47 Tahun 2008 tentang wajib belajar [The Government Regulation Number 47/2008 on Compulsory Education]. Jakarta. $2008 ; 1-12$.

14. Fatkhiyah $\mathrm{N}$, et al. Determinan maternal kejadian preeklampsia di Kabupaten Tegal Jawa Tengah [Determinants of pre-eclampsia in Tegal District, Central Java]. The Soedirman Journal of Nursing. 2016; 11(1): 53-61.

15. Mardiana F. Hubungan Status izi ibu hamil dengan kejadian preeklampsia di RSUP DR.M.Djamil Padang [Association between nutritional status and pre-eclampsia among pregnant women at DR. M. Djamil General Hospital Padang [thesis]. Padang: Andalas University; 2016.

16. Astuti SF. Faktor-faktor yang berhubungan dengan kejadian preeklampsia kehamilan di wilayah kerja Puskesmas Pamulang Kota Tangerang Selatan tahun 2014-2015 [Factors associated with pre-eclampsia during pregnancy at Pamulang Community Health Centre, South Tangerang City 2014-2015] [thesis]. Jakarta: University of Islam Negeri Syarif Hidayatullah; 2015.

17. El-Makhzangy I, Moeity F, Anwer M. Relationship between maternal obesity and increased risk of preeclampsia. Alexandria Journal of Medicine. 2010; 46: 207-212.

18. Dumais CEG, Lengkong RA, Mewengkang ME. Hubungan obesitas pada kehamilan dengan preeklampsia [Association between obesity during pregnancy and pre-eclampsia]. Jurnal E-Clinic. 2016; 4(1).

19. Cnossen JS. Accuracy of body mass index in predicting. International Journal of Gynaecology and Obstetrics. 2007; 1477-1485.

20. Duckitt K, Harrington D. Risk factor for preeclampsia at antenatal booking: Systematic review of controlled studies. BMJ. 2005; 0: 1-7.

21. Ros, Cnattingius S, Lipworth L. Comparison of risk factors for preeclampsia and gestational hypertension in a population-based cohort study. American Journal of Epidemiology. 1998; 147: 1062-1070.

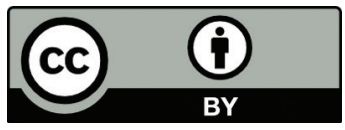

This work is licensed under a Creative Commons Attribution 